\title{
p-Cymene ruthenium thioether complexes
}

\author{
Jadranka Čubrilo a,b, Ingo Hartenbach ${ }^{\mathrm{b}}$, Falk Lissner ${ }^{\mathrm{b}}$, Thomas Schleid ${ }^{\mathrm{b}}$, \\ Mark Niemeyer ${ }^{b}$, Rainer F. Winter ${ }^{\mathrm{a}, *}$ \\ a Institut für Anorganische, Chemie der Universität Regensburg, Universitätsstraße 31, D-93040 Regensburg, Germany \\ ${ }^{\mathrm{b}}$ Institut für Anorganische Chemie der Universität Stuttgart. Pfaffenwaldring 55, D-70569 Stuttgart. Germany
}

\begin{abstract}
Thioethers $\mathrm{PhC}_{2} \mathrm{H}_{4} \mathrm{SMe}, \mathrm{PhC}_{3} \mathrm{H}_{6} \mathrm{~S}^{i} \mathrm{Pr}$ and MeSAllyl form substitutionally labile monomeric adducts ( $p$-cymene) $\mathrm{RuCl}_{2}\left(\mathrm{SRR}^{\prime}\right)$ (2a-c) upon treatment with the $\left\{(p \text {-cymene }) \mathrm{RuCl}_{2}\right\}_{2}$ dimer $\left(p\right.$-cymene $\left.=\eta^{6}-\mathrm{MeC}_{6} \mathrm{H}_{4}{ }^{i} \mathrm{Pr}-1,4\right)$. Pure adducts were obtained by crystallization from $\mathrm{CH}_{2} \mathrm{Cl}_{2} / \mathrm{Et}_{2} \mathrm{O}$, and $2 \mathrm{a}$,c as well as the bis(thioether) complex [ $(p$-cymene $\left.) \mathrm{RuCl}\left(\mathrm{SMe}_{2}\right)^{2}\right]^{+} \mathrm{SbF}_{6}^{-}(3)$ were studied by X-ray crystallography. The trichloro bridged diruthenium complex $\left.[(p \text {-cymene }) \mathrm{Ru}\}_{2}(\mu-\mathrm{Cl})_{3}\right]^{+} \mathrm{SbF}_{6}^{-}$is formed as a byproduct in the preparation of 3 and was also crystallographically characterized. In solution, pure samples $\mathbf{2 a - c}$ equilibrate with free thioether and the dimeric starting complex $\mathbf{1}$. The amount of $\mathbf{1}$ present in these mixtures increases with increasing bulk of the thioether substituents. Attempts to thermally replace the cymene ligand by the dangling arene substituent of the thioether ligand of $\mathbf{2 a , b}$ failed. Complexes $\mathbf{2 a - c}$ as well as the dimethylsufide derivative $\mathbf{2 d}$ were studied by cyclic voltammetry and display a close to reversible (2a,c,d) or partially reversible (2b) oxidation near $+0.85 \mathrm{~V}$ and an irreversible reduction at rather negative potential. New peaks observed after oxidation and reduction point to dissociation of the thioether ligand as the main decomposition pathway of the associated radical cations and anions.
\end{abstract}

\section{Introduction}

Half-sandwich arene complexes of ruthenium with heteroatom donor ligands such as phosphines and amines are being intensively used as catalysts for many important processes. Cationic phosphine substituted allenylidene complexes $\left[\left(\eta^{6} \text {-arene }\right) \mathrm{Cl}\left(\mathrm{PR}_{3}\right) \mathrm{Ru}=\mathrm{C}=\mathrm{C}=\mathrm{CAr}_{2}\right]^{+}$have recently been identified as highly efficient catalysts for olefin metathesis, rivalling the Grubbs carbene systems [1-6]. Simple phosphine adducts $\left(\eta^{6}\right.$-arene $) \mathrm{RuCl}_{2}\left(\mathrm{PR}_{3}\right)$ catalyze the atom transfer radical polymerization (ATRP) of olefins [7,8], the isomerization of allylic alcohols and the hydration of alkynes to ketones or aldehydes [9]. Amine/amide or amine/alkoxy complexes $\left(\eta^{6}\right.$-arene $) \mathrm{Ru}\left(\mathrm{NH}_{2} \mathrm{CHRCHRL}\right) \mathrm{H}$ with

\footnotetext{
" Corresponding author. Tel.: +49941943 4485; fax: +49941943 4488/ 7116854165

E-mail address: rainer.winter@chemie.uni-regensburg.de (R.F. Winter).
}

bifunctional bidentate ligands $(\mathrm{L}=\mathrm{O}$, NTos) are the hallmark of asymmetric hydrogen transfer hydrogenation of ketones [10-13]. Cationic complexes with neutral bidentate chelate ligands have been employed in arene hydrogenation [14], asymmetric Diels-Alder reactions [15,16], hydrogen transfer hydrogenations [17], and styrene polymerization [18], to mention only a few important applications. In contrast to arene half-sandwich complexes bearing phosphine and amine ligands, similar complexes of thioethers have only been little explored, probably because of the inherently weaker $\mathrm{Ru}-\mathrm{SR}_{2}$ bond. Thus, studies by Dixneuf and coworkers have revealed, that thioether adducts $\left(\eta^{6}\right.$-arene) $\mathrm{RuCl}_{2}\left(\mathrm{SR}_{2}\right)$ are labile and exist in equilibrium with their dimeric halide bridged precursors. Dicationic bis(adducts) $\left[\left(\eta^{6} \text {-arene }\right) \mathrm{RuCl}_{2}\left(\mathrm{SR}_{2}\right)_{2}\right]^{+}$are more stable but may still easily exchange one of the thioether moieties for a better donor such as a phosphine [19]. Yamamoto and his coworkers have recently reported on more stable ruthenium thioether complexes with 1,3- and 1,4-dithiane ligands [20]. The use of 
thiacrown or mixed thiol/thiolate chelate ligands also aids to stabilize the ruthenium thioether bond [21-23]. We here report on the synthesis and characterization of thioether adducts ( $p$-cymene) $\mathrm{RuCl}_{2}\left(\mathrm{SR}_{2}\right) \mathbf{2 a}-\mathbf{c}$, including structural characterization of the $\mathrm{MeSC}_{2} \mathrm{H}_{4} \mathrm{Ph}$ (2a) and the $\mathrm{MeSCH}_{2-}$ $\mathrm{CH}=\mathrm{CH}_{2}$ (2c) complexes, which constitute rare examples of simple thioether adducts to be investigated by this method. Also included are the X-ray structures of the bis(thioether) complex $\left[(p \text {-cymene }) \mathrm{RuCl}\left(\mathrm{SMe}_{2}\right)_{2}\right]^{+} \mathrm{SbF}_{6}^{-}$ (3) and of $\left[(p \text {-cymene }) \mathrm{Ru}_{2} \mathrm{Cl}_{3}\right]^{+} \mathrm{SbF}_{6}^{-}$(4). The latter was formed as a by-product in the preparation of compound 3. Redox potentials for the $\mathrm{Ru}(\mathrm{II} / \mathrm{III})$ oxidations and of the irreversible reductions of these complexes were determined by cyclic voltammetry. Some hints as to the degradation pathway of the associated radical cations and anions were obtained from a comparison of their voltammograms with those of $\mathbf{1}$.

\section{Results and discussion}

The monothioether complexes $\mathbf{2 a - c}$ were prepared by reacting dimeric $\left\{(p \text {-cymene }) \mathrm{RuCl}_{2}\right\}_{2}(1)$ in dichloromethane with a slight excess (ca. 1.5 equiv.) of the corresponding thioether (see Chart 1). The new arylalkyl substituted thioethers, isopropyl(3-phenylpropyl)sulfide, $\mathrm{PhC}_{3} \mathrm{H}_{6} \mathrm{~S}^{i} \mathrm{Pr}$, and methyl(2-phenylethyl)sulfide, $\mathrm{PhC}_{2} \mathrm{H}_{4} \mathrm{SMe}$, were prepared according to established procedures via nucleophilic substitution of bromide or iodide by the respective thiolate. Pure thioether complexes could be obtained as orange-red crystals $(\mathbf{2 a}, \mathbf{c})$ or microcrystals $(\mathbf{2 b})$ by recrystallization from dichloromethane/ether mixtures. Simple thioether adducts $\left(\eta^{6}\right.$-arene $) \mathrm{RuCl}_{2}\left(\mathrm{SRR}^{\prime}\right)$ are reportedly labile in solution and exist in equilibrium with the dichloro bridged precursor 1 and free thioether [19]. Ligand dissociation from complexes 2 is readily observed by NMR spectros- copy. While the resonance signals of the dissociated and the coordinated SRR' ligand are usually coalesced, giving just one set of signals, the relative amounts of complexes $2 a-c$ and 1 in the equilibrium mixtures can be determined by integrating the different sets of $\mathrm{CH}$ resonances of the cymene ligands. Values of 12:1, 5:2 and 7.5:1 were obtained for $2 \mathrm{a}-\mathrm{c}$ in $\mathrm{CD}_{2} \mathrm{Cl}_{2}$ respectively. This order roughly corresponds to the steric bulk of the substituents on the thioether ligand. Nearly identical values were obtained by comparing the peak currents of $\mathbf{2 a - c}$ and $\mathbf{1}$ in cyclic voltammetry experiments (see below). The thioether methylene and methyl resonance signals always integrate as $1: 1$ and 3:2, respectively, with the sum of each set of CH-resonance signals of $\mathbf{2} \mathbf{a}-\mathbf{c}$ and $\mathbf{1}$, thus ruling out contamination of the solid adducts by unreacted $\mathbf{1}$. In toluene- $d_{8} \mathbf{2 b}$ initially forms a clear orange solution from which 1 slowly crystallizes. The final solution equilibrium mixture contains free $\mathrm{PhC}_{3} \mathrm{H}_{6} \mathrm{~S} P \mathrm{Pr}$ and $2 \mathbf{b}$ in an approximate $1: 1$ ratio as based on comparison of the integrals of the arene $\mathrm{CH}$ signals of $\mathbf{2} \mathbf{b}$ to those of the thioether methylene protons. A similar $2 \mathbf{b}: 1$ ratio of 1:0.88 was observed in $\mathrm{CD}_{3} \mathrm{OD}$, where 1 remains dissolved. For every thioether complex, the resonance signals of the alkyl substituents neighbouring the $\mathrm{S}$ atom are broadened due to sulfur inversion [24].

Recent work on similar $\left(\eta^{6}\right.$-arene)dichloro complexes bearing arylalkyl substituted phosphines with flexible alkyl spacers has disclosed, that, upon thermal treatment, the coordinated arene is readily replaced by a dangling aryl substituent [3,25-27]. This reaction provides an easy access to tethered complexes where the phosphine substituted arene serves as an eight electron donor chelate ligand. Some of these complexes display reactivities that markedly differ from those of their non-tethered analogs $[28,29]$. In contrast, no such arene substitution was observed for complexes $\mathbf{2} \mathbf{a}, \mathbf{b}$ even in hot chlorobenzene.

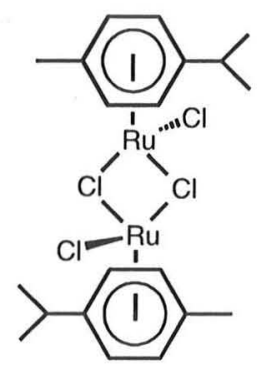

1

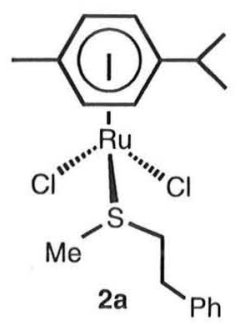

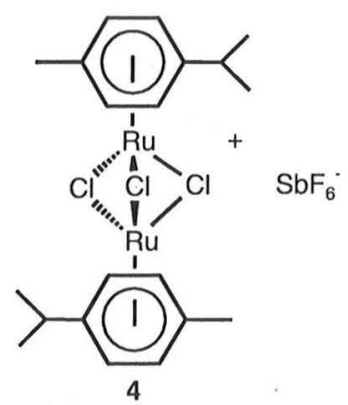

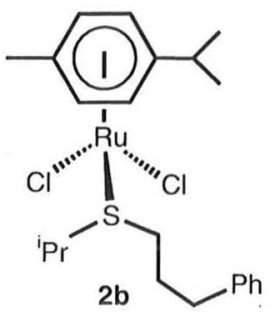

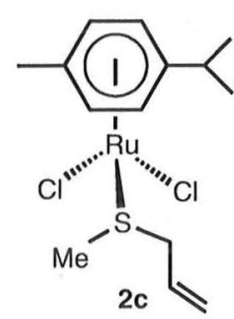

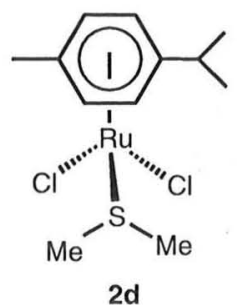

$2 \mathrm{~d}$

Chart 1. Complexes under investigation.

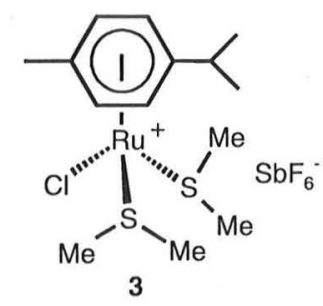


At higher temperatures, e.g. in refluxing 1,2-dichlorobenzene, 2a,b decompose.

Dixneuf had reported that the cationic bis(thioether) complexes $\left[\left(\eta^{6} \text {-arene }\right) \mathrm{RuCl}\left(\mathrm{SMe}_{2}\right)_{2}\right]^{+}$are considerably more stable toward thioether dissociation, yet easily exchange one $\mathrm{SMe}_{2}$ ligand for a better donor like a phosphine to give chiral-at-metal complexes $\left[\left(\eta^{6} \text {-arene }\right) \mathrm{RuCl}\left(\mathrm{SMe}_{2}\right)(\mathrm{L})\right]^{+}$ [19]. In the course of our work we also prepared the cationic $p$-cymene bis(dimethylthioether) complex $\mathbf{3}$ as its $\mathrm{SbF}_{6}^{-}$salt. In our hands, under the conditions reported by Dixneuf, this complex was obtained along with small quantities of the trichloro bridged bis(arene) complex $\left[\{(p \text {-cymene }) \mathrm{Ru}\}_{2}\left(\mu-\mathrm{Cl}_{3}\right)\right]^{+} \mathrm{SbF}_{6}^{-}$(4). Crystallization from ethanol resulted in the crystallization of both 3 and 4 . Crystals of 3 and 4 could be separated based on their different shapes - orange diamond-shaped crystals for $\mathbf{3}$, orange rods for 4 . The structures of both complexes were determined by X-ray diffraction as it will be discussed in the following section.

The reaction of thioether and bis(thioether) chloro ruthenium complexes with terminal alkynes in methanol was reported to give methoxycarbenes $\left[\left(\eta^{6}\right.\right.$-arene $) \mathrm{Cl}\left(\mathrm{SMe}_{2}\right)$ $\left.\mathrm{Ru}=\mathrm{C}(\mathrm{OMe}) \mathrm{CH}_{2} \mathrm{Ph}\right]^{+}$, most probably via vinylidene intermediates [19]. In trying to access similar half-sandwich ruthenium allenylidene or vinylidene derivatives with thioether ligands, 2a,c and $\left[(p \text {-cymene }) \mathrm{RuCl}\left(\mathrm{SMe}_{2}\right)_{2}\right]^{+}$(3) were reacted with 1,1-diphenyl-prop-2-yn-1-ol, 2-phenylbutynol, 2-methylbutynol or $\mathrm{AgSbF}_{6} / 1,1$-diphenyl-prop-2-yn-1-ol in dichloromethane or methanol. These reactions either did not proceed at all (3) or led to the formation of dark orange, oily unidentified mixtures. The absence of any allenylidene or vinylidene IR bands in these mixtures points to the fact that such complexes, if formed at all, are too unstable to allow for their isolation.

\section{X-ray structure determinations of $2 a, c, 3$ and 4}

Crystals of compounds $\mathbf{2 a}, \mathbf{c}, \mathbf{3}$ and $\mathbf{4}$ were grown by slow diffusion of ether into a concentrated solution of the respective complex in $\mathrm{CH}_{2} \mathrm{Cl}_{2}$ and investigated by $\mathrm{X}$-ray crystallography. Figs. 1-4 display the structures of the complexes or complex cations in the solid state. The most important interatomic distances and bond angles are collected in Tables 1 and 2 while Table 3 provides information pertinent to the data collection and refinement.

The complexes ( $p$-cymene) $\mathrm{RuCl}_{2}\left(\mathrm{MeSC}_{2} \mathrm{H}_{4} \mathrm{Ph}\right)$ (2a), (p-cymene) $\mathrm{RuCl}_{2}\left(\mathrm{MeSC}_{3} \mathrm{H}_{5}\right)(2 \mathrm{c})$ and $[(p$-cymene $) \mathrm{RuCl}$ $\left.\left(\mathrm{SMe}_{2}\right)\right]^{+} \mathrm{SbF}_{6}^{-}$(3) represent rare examples of structurally characterized (arene) $\mathrm{Ru}$ complexes bearing simple thioether ligands. In $\mathbf{2 a}, \mathbf{c}$, two chloride and the thioether ligands occupy cis-disposed coordination sites and form three nearly equally long legs of the piano-stool structure which is archetypical of $\left[\left(\eta^{6}\right.\right.$-arene $\left.) \mathrm{RuL}_{3}\right]$ half-sandwich arene complexes. The $\mathrm{Ru}-\mathrm{S}$ bond lengths are close to $2.40 \AA$ (2.4032(8) $\AA$ in 2a and 2.3978(8) $\AA$ in 2c) and are slightly longer than the corresponding $\mathrm{Ru}-\mathrm{S}$ bond length of 2.357(4) $\AA$ in ( $p$-cymene) $\mathrm{RuCl}_{2}$ (1,3-dithiane) [20]. Shorter

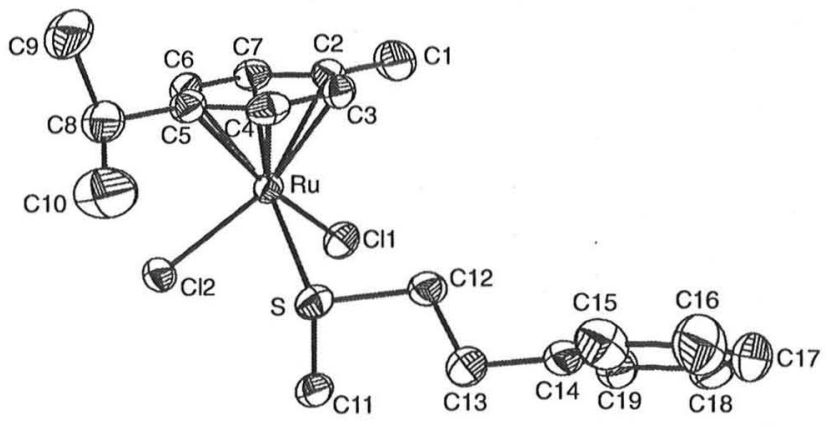

Fig. 1. Structure of the thioether complex $2 \mathrm{a}$ in the solid state with the atom numbering. Thermal ellipsoids are drawn at a $50 \%$ probability level.

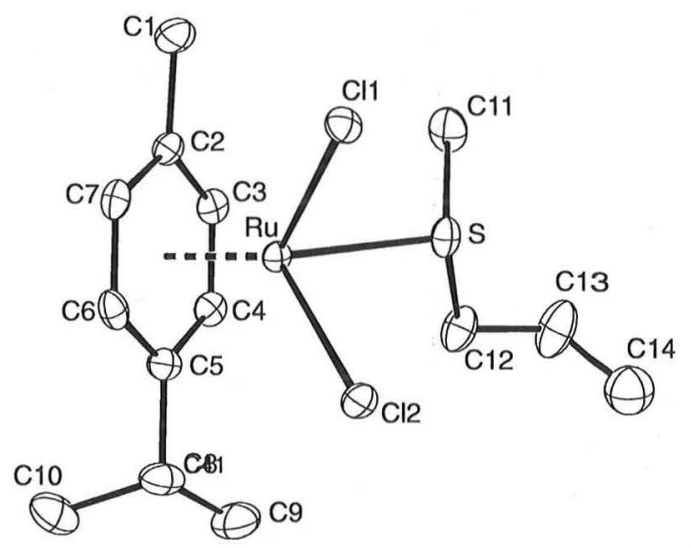

Fig. 2. Structure of the thioether complex $2 \mathrm{c}$ in the solid state with the atom numbering. Thermal ellipsoids are drawn at a $50 \%$ probability level.

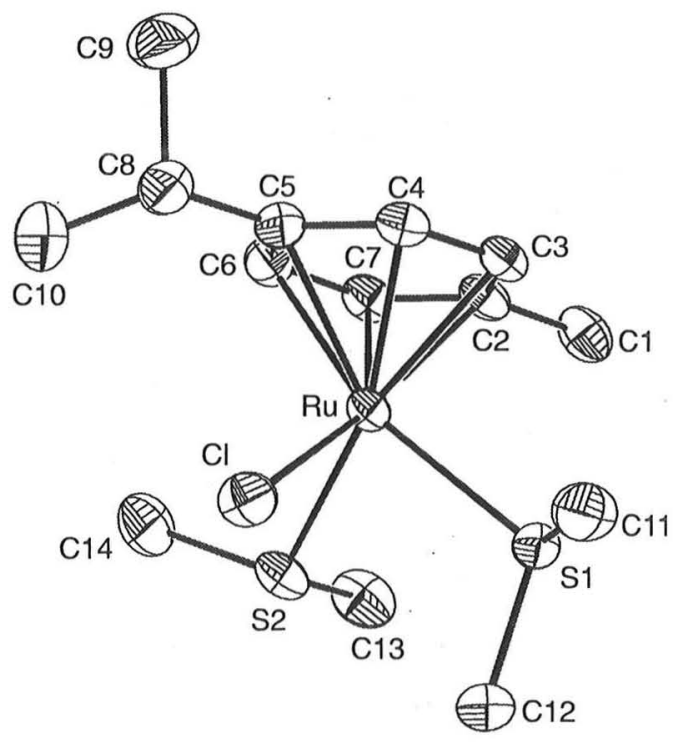

Fig. 3. Structure of the complex cation in complex $\mathbf{3}$ in the solid state with the atom numbering. Thermal ellipsoids are drawn at a $50 \%$ probability level.

$\mathrm{Ru}-\mathrm{S}$ bonds are observed in arene half-sandwich complexes where the thioether moiety is part of a macrocycle [22] or a mixed thioether thiolate chelate ligand $[21,22]$. 


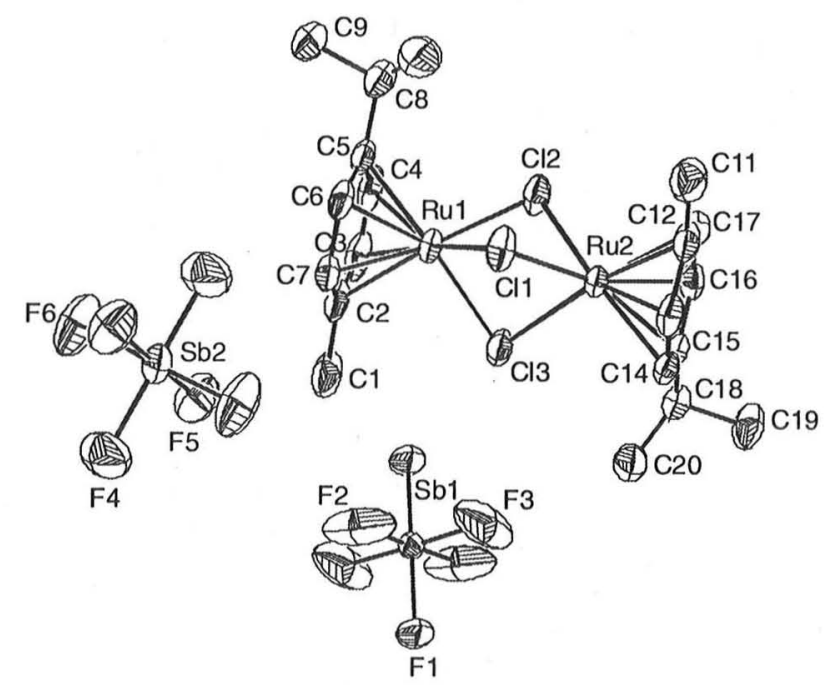

Fig. 4. Structure of $\left[\{(p \text {-cymene }) \mathrm{Ru}\}_{2} \mathrm{Cl}_{3}\right]^{+} \mathrm{SbF}_{6}^{-}(3)$ in the solid state. Note that the $\mathrm{Sb}$ atoms reside on special positions $\{\mathrm{Sbl} / \mathrm{Sb} 1 \mathrm{a}:(0,0,1 / 2)$ and $(0,1,1 / 2)$, respectively and $\mathrm{Sb} 2 / \mathrm{Sb} 2 \mathrm{a}(1 / 2,1,0)$ bzw. $(1 / 2,0,1)$, respectively $\}$ and are thus related by an inversion centre. Thermal ellipsoids are drawn at a $50 \%$ probability level.

Table 1

Interatomic distances and bond angles for complexes $\mathbf{2 a , c}$ and 3

\begin{tabular}{llll}
\hline & $2 \mathrm{a}$ & $\mathbf{2 c}$ & $\mathbf{3}$ \\
\hline $\mathrm{Ru}-\mathrm{C} 2$ & $2.215(3)$ & $2.191(2)$ & $2.220(3)$ \\
$\mathrm{Ru}-\mathrm{C} 3$ & $2.177(3)$ & $2.165(2)$ & $2.200(3)$ \\
$\mathrm{Ru}-\mathrm{C} 4$ & $2.149(3)$ & $2.187(3)$ & $2.198(3)$ \\
$\mathrm{Ru}-\mathrm{C} 5$ & $2.194(3)$ & $2.207(2)$ & $2.239(3)$ \\
$\mathrm{Ru}-\mathrm{C} 6$ & $2.178(3)$ & $2.200(2)$ & $2.227(3)$ \\
$\mathrm{Ru}-\mathrm{C} 7$ & $2.191(3)$ & $2.190(2)$ & $2.183(3)$ \\
$\mathrm{Ru}-\mathrm{Cl}$ & $2.4108(8)$, & $2.4104(7)$, & $2.3944(7)$ \\
& $2.4389(8)$ & $2.4121(11)$ & \\
$\mathrm{Ru}-\mathrm{S}$ & $2.4032(8)$ & $2.3978(8)$ & $2.3833(7)$, \\
& & & $2.3881(7)$ \\
$\mathrm{S}-\mathrm{C} 11, \mathrm{~S}-\mathrm{C} 13^{\mathrm{a}}$ & $1.806(4)$ & $1.811(3)$ & $1.797(4)$, \\
& & & $1.797(4)$ \\
$\mathrm{S}-\mathrm{C} 12, \mathrm{~S}-\mathrm{C} 14^{\mathrm{a}}$ & $1.848(4)$ & $1.824(4)$ & $1.800(4)$, \\
& & & $1.792(4)$ \\
$\mathrm{Cl}-\mathrm{Ru}-\mathrm{Cl}$ & $89.52(3)$ & $88.31(4)$ & \\
$\mathrm{Cl}-\mathrm{Ru}-\mathrm{S}$ & $88.14(3)$, & $80.37(2)$, & $87.68(3)$, \\
$\mathrm{S}-\mathrm{Ru}-\mathrm{S}$ & $84.51(3)$ & $81.50(2)$ & $81.86(3)$ \\
\hline
\end{tabular}

a For 3.
In such complexes $\mathrm{Ru}-\mathrm{S}$ bond lengths usually range from 2.30 to $2.34 \AA$. The longer $\mathrm{Ru}-\mathrm{S}$ bonds reflect the inherent weakness of the unsupported $\mathrm{Ru}-\mathrm{S}$ (thioether) bond as it is evident from the ready dissociation of the $\mathrm{SR}_{2}$ ligand and partial formation of dichloro bridged $\left\{\left(\eta^{6} \text {-arene }\right) \mathrm{RuCl}_{2}\right\}_{2}$ dimers. Bond angles subtended by the ligands forming the legs and the ruthenium atom are all close $90^{\circ}$ in $2 \mathbf{a}$ $\left(\mathrm{Cl} 1-\mathrm{Ru}-\mathrm{Cl} 2=89.52(3)^{\circ}, \quad \mathrm{Cl} 1-\mathrm{Ru}-\mathrm{S}=88.14(3)^{\circ}, \quad \mathrm{Cl} 2-\right.$ $\left.\mathrm{Ru}-\mathrm{S}=84.51(3)^{\circ}\right)$ and attest to the overall octahedral coordination of the metal atom. Larger deviations from this geometry are observed for $2 \mathrm{c}$, where the $\mathrm{S}-\mathrm{Ru}-\mathrm{Cl}$ angles are somewhat acute at $80.37(2)$ and $81.50(2)^{\circ}$. The $\mathrm{Ru}-\mathrm{Cl}$ bond lengths of $2.4108(8)$ and $2.4389(8) \AA$ (2a) or 2.4104(7) and 2.4121(11) (2c) are unexceptional for monomeric dichloro arene ruthenium complexes featuring neutral two-electron donor ligands L like, e. g. $\left(\eta^{6}-\right.$ $\left.\mathrm{C}_{6} \mathrm{Me}_{3} \mathrm{H}_{3}\right) \mathrm{RuCl}_{2}$ (pyridine) (2.419(2), 2.415(2) $\mathrm{\AA}$ ) [30], (p-cymene) $\mathrm{RuCl}_{2}$ (2-aminopyridine) (2.405(3) and 2.402(3) $\AA$ ) [31], and ( $p$-cymene) $\mathrm{RuCl}_{2}$ (1,3-dithiane) $(2.389(5)$ and $2.406(4) \AA)[20]$. The $\mathrm{Ru}-\mathrm{C}($ cymene) bond lengths vary from $2.149(3) \AA$ to $2.215(3) \AA$. In $2 \mathrm{a}$, the longest $\mathrm{Ru}-\mathrm{C}$ bond involves the methyl substituted carbon atom $\mathrm{C} 2$ as it is observed for many cymene ruthenium complexes, while this is not the case for $2 \mathbf{c}$. The arene rings display a distinct $\mathrm{C}-\mathrm{C}$ bond length alternation, and the average values of the long and short bonds differ by $0.02 \AA$. Essentially the same pattern is also observed for the bis(thioether) complex 3 and for one of the cymene ligands of the trichloro bridged dimer 4 (vide infra).

The structure of the complex cation of $\mathbf{3}$ (see Fig. 3) resembles that of $\mathbf{2 a}, \mathbf{c}$ in all its main structural characteristics i.e. its three legged piano stool geometry with three essentially equally long legs. When comparing the structures of 2a,c and of $\mathbf{3}$, a small yet significant decrease in $\mathrm{Ru}-\mathrm{S}$ bond lengths to 2.3833(7) and 2.3881(7) $\AA$ and of the $\mathrm{RuCl}$ bond length to $2.3944(7) \AA$ is observed. Similar values were observed for $\left[(p\right.$-cymene $) \operatorname{RuCl}\left(\eta^{1}: \eta^{1}-1\right.$, 4-dithiane $)]^{+} \mathrm{PF}_{6}^{-}[20]$. This may be ascribed to the overall positive charge of the complex resulting in a stronger attraction between the metal atom and the electron-rich donor ligands and slightly shorter bond lengths. In contrast, the $\mathrm{Ru}-\mathrm{C}$ bonds become slightly longer and their average value increases from $2.185 \AA$ in $2 \mathrm{a}$ or $2.190 \AA$ in 2c to $2.211 \AA$ in 3 . In the crystalline state the two thioether ligands adopt different orientations with respect to the

Table 2

Interatomic distances and bond angles for $\left[\left\{(p \text {-cymene }) \mathrm{Ru}_{2} \mathrm{Cl}_{3}\right]^{+} \mathrm{SbF}_{6}^{-}(4)\right.$

\begin{tabular}{|c|c|c|c|c|c|}
\hline Rul-Cll & $2.4238(12)$ & $\mathrm{Ru} 1-\mathrm{Cl} 2$ & $2.4316(13)$ & $\mathrm{Ru} 1-\mathrm{Cl} 3$ & $2.4299(13)$ \\
\hline $\mathrm{Ru} 2-\mathrm{Cll}$ & $2.4341(11)$ & $\mathrm{Ru} 2-\mathrm{Cl} 2$ & $2.4307(12)$ & $\mathrm{Ru} 2-\mathrm{Cl} 3$ & $2.4324(13)$ \\
\hline $\mathrm{Ru} 1-\mathrm{C} 2$ & $2.176(6)$ & Rul-C3 & $2.157(6)$ & Rul-C4 & $2.143(6)$ \\
\hline Ru1-C5 & $2.184(5)$ & Ru1-C6 & $2.147(4)$ & Rul-C7 & $2.174(5)$ \\
\hline $\mathrm{Ru} 2-\mathrm{C} 12$ & $2.172(5)$ & $\mathrm{Ru} 2-\mathrm{C} 13$ & $2.139(5)$ & $\mathrm{Ru} 2-\mathrm{C} 14$ & $2.171(5)$ \\
\hline $\mathrm{Ru} 2-\mathrm{C} 15$ & $2.204(4)$ & $\mathrm{Ru} 2-\mathrm{C} 16$ & $2.165(5)$ & $\mathrm{Ru} 2-\mathrm{C} 17$ & $2.163(5)$ \\
\hline $\mathrm{Cl} 1-\mathrm{Ru} 1-\mathrm{Cl} 2$ & $79.61(4)$ & $\mathrm{Cl} 2-\mathrm{Ru} 1-\mathrm{Cl} 3$ & $79.17(5)$ & $\mathrm{Cl} 1-\mathrm{Ru} 1-\mathrm{Cl} 3$ & $79.53(5)$ \\
\hline $\mathrm{Cl} 1-\mathrm{Ru} 2-\mathrm{Cl} 2$ & $79.42(4)$ & $\mathrm{Cl} 2-\mathrm{Ru} 2-\mathrm{Cl} 3$ & $79.14(5)$ & $\mathrm{Cl} 1-\mathrm{Ru} 2-\mathrm{Cl} 3$ & $79.28(5)$ \\
\hline Ru1-Cl1-Ru2 & $85.07(4)$ & $\mathrm{Ru} 1-\mathrm{Cl} 2-\mathrm{Ru} 2$ & $84.97(4)$ & $\mathrm{Ru} 1-\mathrm{Cl} 3-\mathrm{Ru} 2$ & $84.97(4)$ \\
\hline
\end{tabular}


Table 3

Data pertaining to the data collection and structure refinement for complexes $2 \mathbf{a}, \mathbf{c}, 3$ and 4

\begin{tabular}{|c|c|c|c|c|}
\hline Compound & $2 a$ & $2 \mathrm{c}$ & 3 & 4 \\
\hline $\begin{array}{l}\text { Empirical formula/f. wt. (g/ } \\
\text { mol) }\end{array}$ & $\mathrm{C}_{19} \mathrm{H}_{26} \mathrm{Cl}_{2} \mathrm{RuS} / 458.43$ & $\begin{array}{l}\mathrm{C}_{14} \mathrm{H}_{22} \mathrm{Cl}_{2} \mathrm{RuS} \times 1 / 2 \\
\mathrm{CH}_{2} \mathrm{Cl}_{2} / 436.81\end{array}$ & $\mathrm{C}_{14} \mathrm{H}_{26} \mathrm{ClF}_{6} \mathrm{RuS}_{2} \mathrm{Sb} / 630.74$ & $\mathrm{C}_{20} \mathrm{H}_{28} \mathrm{Cl}_{3} \mathrm{~F}_{6} \mathrm{Ru}_{2} \mathrm{Sb} / 812.66$ \\
\hline Temperature (K) & $293(2)$ & $173(2)$ & $293(2)$ & $293(2)$ \\
\hline Crystal system & Monoclinic & Monoclinic & Monoclinic & Triclinic \\
\hline Space group & $P 2_{1} / n$ & $C 2 / c$ & $P 2_{1} / c$ & $P \overline{1}$ \\
\hline Unit cell dimensions & & & & . \\
\hline$a(\AA)$ & $11.2219(2)$ & $22.674(5)$ & $8.4828(1)$ & $8.2786(1)$ \\
\hline$b(\AA)$ & $12.1458(2)$ & $15.857(3)$ & $17.2331(2)$ & $10.6537(2)$ \\
\hline$c(\AA)$ & $14.8970(2)$ & $11.948(2)$ & $15.2935(2)$ & $16.6834(2)$ \\
\hline$\alpha\left({ }^{\circ}\right)$ & & & & $99.094(1)$ \\
\hline$\beta\left(^{\circ}\right)$ & $90.455(1)$ & $120.58(3)$ & $93.369(1)$ & $101.480(1)$ \\
\hline$\gamma\left({ }^{\circ}\right)$ & & & & $108.578(1)$ \\
\hline$V\left(\AA^{3}\right)$ & $2030.38(6)$ & $3698.3(13)$ & $2231.82(5)$ & $1327.45(3)$ \\
\hline$Z$ & 4 & 8 & 4 & 2 \\
\hline$D_{\text {calc }}\left(\mathrm{Mg} / \mathrm{m}^{3}\right)$ & 1.500 & 1.569 & 1.877 & 2.033 \\
\hline $\begin{array}{l}\text { Absorption coefficient } \\
\left(\mathrm{mm}^{-1}\right)\end{array}$ & 1.135 & 1.382 & 2.238 & 2.485 \\
\hline $\begin{array}{l}\theta \text { Range for data collection } \\
\left({ }^{\circ}\right)\end{array}$ & $2.82-27.48$ & $2.13-27.99$ & $2.71-27.50$ & $2.57-27.40$ \\
\hline Limiting Indices & $\begin{array}{l}-14<h<14 \\
-15<k<15 \\
-19<l<19\end{array}$ & $\begin{array}{l}-29<h<25 \\
-20<k<7 \\
-15<l<15\end{array}$ & $\begin{array}{l}-11<h<11 \\
-22<k<22 \\
-17<l<19\end{array}$ & $\begin{array}{l}-10<h<10 \\
-13<k<13 \\
-21<l<21\end{array}$ \\
\hline $\begin{array}{l}\text { Reflections collected/unique }{ }^{\mathrm{a}} \\
\quad\left(R_{\mathrm{int}}\right)\end{array}$ & $41082 / 4639(0.0499)$ & $4660 / 4550(0.0337)$ & $46487 / 5111(0.0512)$ & $47238 / 6040(0.0832)$ \\
\hline Data/restraints/parameter & $4639 / 0 / 313$ & $4550 / 2 / 183$ & $5111 / 0 / 246$ & $6040 / 0 / 331$ \\
\hline$R(I>2 \sigma(I))$ & $R_{1}=0.0350, w R_{2}=0.0801$ & $R_{1}=0.0332, w R_{2}=0.1044$ & $R_{1}=0.0313, w R_{2}=0.0750$ & $R_{1}=0.0460, w R_{2}=0.0853$ \\
\hline$R_{\mathrm{wv}}$ (all data) & $R_{1}=0.0444, w R_{2}=0.0844$ & $R_{1}=0.0350, w R_{2}=0.1054$ & $R_{1}=0.0342, w R_{2}=0.0770$ & $R_{1}=0.0694, w R_{2}=0.0882$ \\
\hline GooF (all Data) & 1.080 & 1.853 & 1.146 & 1.926 \\
\hline $\begin{array}{l}\text { Maximum and minimum res. } \\
\text { dens. }\left(\mathrm{e}^{-3} \text { ) }\right.\end{array}$ & 0.591 and -0.515 & 1.352 and -1.314 & 0.736 and -0.885 & 1.053 and -0.686 \\
\hline
\end{tabular}

a $I \geqslant 3 \sigma(I)$.

arene ligand. While the methyl groups on $\mathrm{S} 1$ are in an exoposition with the methyl groups pointing away from the cymene ligand the opposite is true for the second thioether ligand associated with $\mathrm{S} 2$.

The structure of the dinuclear complex 4 is shown in Fig. 3. A view of the unit cell may be found as Fig. 1 of the Supplementary material. The complex cation adopts the familiar structure of two face-sharing octahedra with the arene ligands and the three chlorine atoms as the opposite faces. This motif is highly common of complexes of the general composition $\left[\mathrm{L}_{3} \mathrm{M}\left(\mu-\mathrm{L}^{\prime}\right)_{3} \mathrm{ML}_{3}\right]^{n+}$ and has ample precedence in arene ruthenium chemistry [32]. Individual arene and $\mathrm{Cl}_{3}$ planes are nearly parallel to each other with angles between their normals of $2.69^{\circ}\left(\right.$ Arene $\left.1-\mathrm{Cl}_{3}\right), 0.28^{\circ}$ (Arene2- $\mathrm{Cl}_{3}$ ) and $2.87^{\circ}$ (Arene1-Arene2), where Arene1 and Arene 2 denote the arene ligands bonded to atoms $\mathrm{Ru} 1$ and $\mathrm{Ru} 2$, respectively. The metal atoms are slightly shifted off-centre toward the common $\mathrm{Cl}_{3}$ face of the bisoctahedron. Thus, the $\mathrm{Ru}-\mathrm{Cl}_{3}$ distances amount to $1: 640 \AA$ $\left(\mathrm{Rul}-\mathrm{Cl}_{3}\right)$ and $1.644 \AA\left(\mathrm{Ru} 2-\mathrm{Cl}_{3}\right)$ while the $\mathrm{Ru}$ atoms are $1.647 \AA(\mathrm{Ru} 1)$ and $1.651 \AA(\mathrm{Ru} 2)$ away from the corresponding arene planes. $\mathrm{Ru}-\mathrm{Cl}$ distances range from $2.4238(12)$ to $2.4341(11) \AA$ and are thus slightly longer than typical bonds to terminal chloride ligands as in complexes 2 or 3. The $\mathrm{Ru}-\mathrm{Cl}$ distances in 4 also match well with the literature data of other complexes of the type $\left[\left\{\left(\eta^{6}\right.\right.\right.$-are- ne) $\left.\mathrm{Ru}\}_{2}(\mu-\mathrm{Cl})_{3}\right]^{+}$where arene is $\mathrm{C}_{6} \mathrm{H}_{6}$, toluene [33], $\mathrm{C}_{6} \mathrm{Me}_{6}$ [34], or ethoxybenzene [35], and with the bis(p-cymene) complex $\left[\{(p \text {-cymene }) \mathrm{Ru}\}_{2}(\mu-\mathrm{Cl})_{3}\right]^{+} \mathrm{BPh}_{4}^{-}$[36]. Owing to restrictions imposed by face-sharing, the $\mathrm{Cl}-\mathrm{Ru}-\mathrm{Cl}$ angles lie in a narrow range from $79.14(5)$ to $79.61(4)^{\circ}$. The $\mathrm{Ru}-$ $\mathrm{Cl}-\mathrm{Ru}$ angles are all close to $85^{\circ}$ and this again closely resembles the values of $\left[\{(p \text {-cymene }) \mathrm{Ru}\}_{2}(\mu-\mathrm{Cl})_{3}\right]^{+} \mathrm{BPh}_{4}^{-}$, where these angles range from 84.1 to $86.1^{\circ}$. $\mathrm{Ru}-\mathrm{C}$ bonds are in the range from $2.139(5)$ and 2.204(4) $\AA$. For each cymene ligand, the longest $\mathrm{Ru}-\mathrm{C}$ bond involves the $\mathrm{C}$ atom that bears the ${ }^{i} \mathrm{Pr}$ group. The cymene ligands at $\mathrm{Ru}(1)$ and $\mathrm{Ru}(2)$ differ in the orientation of the ${ }^{i} \mathrm{Pr}$-substituents as it is shown by the torsional angles of $\mathrm{C}(4)-\mathrm{C}(5)-\mathrm{C}(8)-$ $\mathrm{C}(9)=93.7(9)^{\circ}$ for $\mathrm{Ru}(1)$, resembling an orthogonal orientation with respect to the ring plane, and $\mathrm{C}(14)$ $\mathrm{C}(15)-\mathrm{C}(18)-\mathrm{C}(20)=30.8(7)^{\circ}$ for $\mathrm{Ru}(2)$.

The related complexes $\left[\left\{\left(\eta^{6}-\mathrm{C}_{6} \mathrm{H}_{6}\right) \mathrm{Ru}_{2} \mathrm{Cl}_{3}\right]^{+} \mathrm{BF}_{4}^{--}\right.$and $\left[\left\{\left(\eta^{6}-\mathrm{C}_{6} \mathrm{H}_{5} \mathrm{Me}\right) \mathrm{Ru}\right\}_{2} \mathrm{Cl}_{3}\right]^{+} \mathrm{BF}_{4}^{-}$display interesting intermolecular interactions based on short $\mathrm{CH} \cdots \mathrm{Cl}$ and $\mathrm{CH} \cdots \mathrm{F}$ contacts between arene $\mathrm{CH}$ and the bridging chloride ligands or the $\mathrm{F}$-atoms of the $\mathrm{BF}_{4}^{-}$counterions [33]. In 4, the ${ }^{i} \mathrm{Pr}$ and the methyl substituents on the arene induce much larger anion/cation separations and prevent the formation of such a hydrogen bonding network (see Fig. 1 of the Supplementary material). All $\mathrm{CH} \cdots \mathrm{Cl}$ contacts are longer than $2.93 \AA$ and are thus, at best, only slightly 
shorter than the sum of the van der Waals radii. The same holds for possible interion hydrogen bonded contacts to the $\mathrm{SbF}_{6}^{-}$counterion. Two notable exceptions are the short $\mathrm{CH}$...F contacts between atoms $\mathrm{F} 2$ and the hydrogen atom attached to $\mathrm{C} 17(2.440 \AA)$ and atoms F4 and the hydrogen atom at C7 (2.469 $\AA$ ). All other $\mathrm{CH}$...F distances are identical to or larger than the sum of the van der Waals radii $(2.55 \AA)$.

\section{Electrochemistry}

The thioether complexes $\mathbf{2 a - c}$, known ( $p$-cymene) $\mathrm{RuCl}_{2^{-}}$ $\left(\mathrm{SMe}_{2}\right)(\mathbf{2 d})$, and the bis(thioether) adduct $\mathbf{3}$ (see Chart 1) were studied by cyclic voltammetry. Relevant data are compiled in Table 4. Figs. 5 and 6 display voltammograms recorded for complexes $\mathbf{2 b}$ and $\mathbf{2 c}$ as a representative examples.

All complexes undergo one partially to nearly reversible oxidation and one chemically completely irreversible reduction within the potential window of the $\mathrm{CH}_{2} \mathrm{Cl}_{2}$ / $\mathrm{NBu}_{4} \mathrm{PF}_{6}$ supporting electrolyte. The one-electron nature

Table 4

Voltammetry data for complexes $\mathbf{1}, \mathbf{2 a - d ,} 3\left(\mathrm{CH}_{2} \mathrm{Cl}_{2} / 0.1 \mathrm{M} \mathrm{NBu}_{4} \mathrm{PF}_{6}\right)$

\begin{tabular}{llll}
\hline Compound & $E_{\mathrm{ox}}^{1 / 2}(\mathrm{~V})$ & $E_{\mathrm{p}, \mathrm{c}}{ }^{\mathrm{a}}(\mathrm{V})$ & $E_{\mathrm{p}, \mathrm{a} \text { follow }}{ }^{\mathrm{b}}(\mathrm{V})$ \\
\hline $\mathbf{2 a}$ & 0.85 & -2.09 & -0.58 \\
2b & 0.85 & $\mathrm{c}$ & -0.58 \\
2c & 0.845 & -2.02 & -0.58 \\
$\mathbf{2 d}$ & 0.83 & -2.19 & -0.58 \\
$\mathbf{3}$ & 1.44 & -1.57 & -0.50 \\
$\mathbf{1}$ & 1.04 & $-1.36,-1.98$ & -0.57 \\
\hline
\end{tabular}

Potentials are reported vs. the ferrocene/ferrocenium couple.

a Peak potential of an irreversible process.

b Potential of the irreversible anodic peak following reduction.

c Reduction peak overlapped with the second irreversible multielectron reduction wave of 1 .

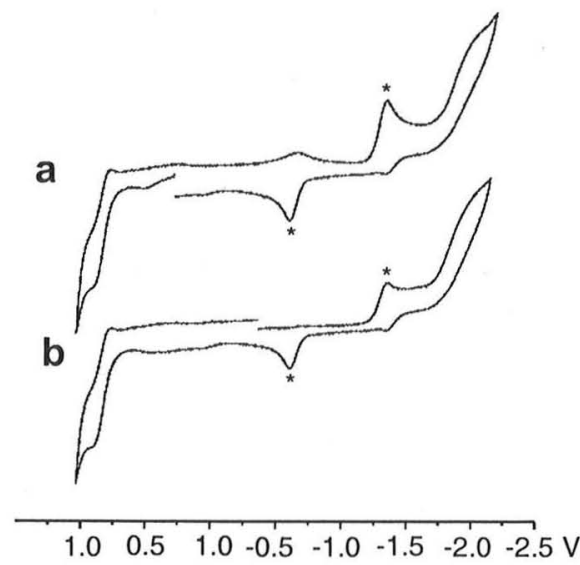

Fig. 5. Cyclic voltammograms of complex 2b in $\mathrm{CH}_{2} \mathrm{Cl}_{2} / \mathrm{NBu}_{4} \mathrm{PF}_{6}$ $(0.1 \mathrm{M})$ at RT and $v=0.1 \mathrm{~V} / \mathrm{s}$. (a) Oxidation scanned first; (b) reduction scanned first. The peaks due to the reduction of 1 and to the oxidation of the electroactive product formed from the radical anion of $\mathbf{1}$ are indicated by a star symbol.

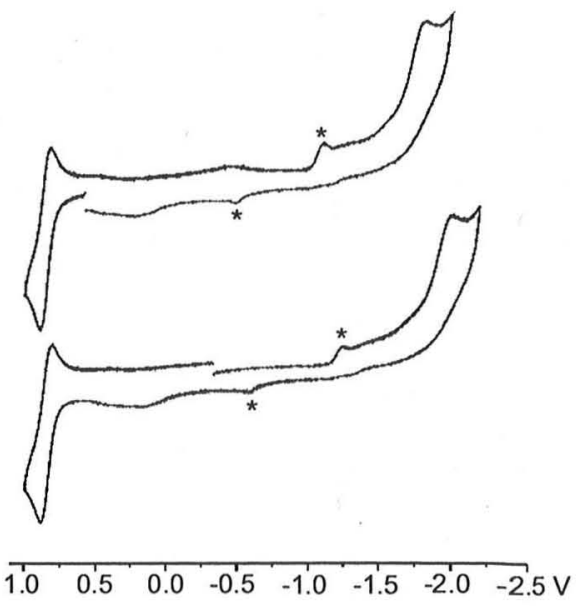

Fig. 6. Cyclic voltammograms of complex $2 \mathrm{c}$ in $\mathrm{CH}_{2} \mathrm{Cl}_{2} / \mathrm{NBu}_{4} \mathrm{PF}_{6}(0.1 \mathrm{M})$ at $\mathrm{RT}$ and $v=0.1 \mathrm{~V} / \mathrm{s}$. Upper curve: oxidation scanned first, lower curve: reduction scanned first. The peaks due to the reduction of $\mathbf{1}$ and to the oxidation of the electroactive product formed from the radical anion of 1 are indicated by a star symbol.

of these waves was ascertained from peak potential separations and peak currents that resemble those of the internal ferrocene standard present at equimolar concentration (cyclic voltammetry), as well as peak half-widths (square wave voltammetry) that correspond to the values expected for this stoichiometry and from nearly identical peak currents associated with the oxidation and the reduction processes. At sweep rates of about $1 \mathrm{~V} / \mathrm{s}$ or larger, peak-to-peak separations of the ruthenium complexes are notably larger than those of the internal ferrocene standard, pointing to slightly lower electron transfer kinetics for the ruthenium complexes. Chemical processes following oxidation could be fully suppressed by applying higher sweep rates or lowering the temperature, and full chemical reversibility was attained at $195 \mathrm{~K}$ in each case. Reduction, however, remained a completely irreversible process. The mono(thioether) complexes undergo oxidation at potentials near $0.85 \mathrm{~V}$ whereas the cationic bis(thioether) derivative 3 is much harder to oxidize and gives an $E_{1 / 2}$ of $+1.44 \mathrm{~V}$. The oxidation potentials of $\mathbf{2 a}-\mathbf{c}$ and of the related $\mathrm{SMe}_{2}$ derived complex $\mathbf{2 d}$ are by about $100 \mathrm{mV}$ higher than those of similar phosphine derivatives [26,37-39], and this signals that $\mathrm{SR}_{2}$ ligands are inferior electron donors compared to phosphines. A similar anodic shift is seen for the reduction peak potential of $\mathbf{3}$ compared to $\mathbf{2 a - c}$. The strong influence of the complex charge on the oxidation and reduction potentials indicates that both processes are centred on the metal rather than at a ligand as it is common for half-sandwich ruthenium complexes. Irreversibility of the reduction step usually arises from ligand dissociation from a reactive $\mathrm{Ru}(\mathrm{I})$ species [40]. When the scan is reversed following reduction a new anodic peak appears. This feature is com-

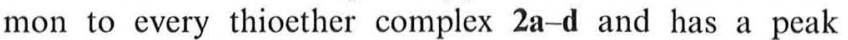
potential of $-0.58 \mathrm{~V}$ (see Figs. 5 and 6). A similar feature with exactly the same peak potential is observed on the 
anodic reverse scan following the reduction of $\{(p$-cymene) $\left.\mathrm{RuCl}_{2}\right\}_{2}$ (1). This latter feature has been assigned as arising from $\left\{(p\right.$-cymene $) \mathrm{RuCl}_{2}$, which in turn results from 1 by a sequence of reduction and chloride dissociation steps [40]. Such a coincidence may be fortuitous, but the formation of a common product from the reduction of thioether complexes $\mathbf{2 a - d}$ still suggests that decomposition of the reduced forms involves dissociation of the SRR' ligand.

Voltammograms of 2a-c (see Fig. 5) also displayed a distinct reduction peak at $-1.37 \mathrm{~V}$. This peak was identified as arising from the reduction of $\left\{(p \text {-cymene }) \mathrm{RuCl}_{2}\right\}_{2}$, (1), by comparison with an authentic sample (see Fig. 2 of the Supplementary material) and by comparing voltammograms before and after addition of small amounts of 1 to the solutions of $\mathbf{2 a - d}$. Relative amounts of $\mathbf{2 a - d}$ and $\mathbf{1}$ present in the equilibrated electrolyte solution were estimated as $11: 1,5: 2,7: 1$, and $12: 1$ by comparing the peak currents of the partially reversible oxidation of $\mathbf{2 a - d}$ and of the reduction peak of $\mathbf{1}$ in good agreement with the ratios determined by NMR spectroscopy. As it is shown in Figs. 5 and 6 , the peak at $-1.37 \mathrm{~V}$ of 1 present in the equilibrated solutions is enhanced when the partially reversible oxidation is scanned first. Thioether dissociation thus also constitutes a likely degradation pathway for the $\left[(p \text {-cymene }) \mathrm{RuC}_{2}\left(\mathrm{SRR}^{\prime}\right)\right]^{+}$radical cations formed during the oxidation step. This is also in line with the observation that complex 2 b with $\mathrm{PhC}_{3} \mathrm{H}_{6} \mathrm{~S}^{i} \mathrm{Pr}$ as the sterically most demanding and most weakly coordinated thioether gives the least stable radical cation, i.e. the one with the smallest $i_{\mathrm{p}, \mathrm{c}} / i_{\mathrm{p}, \mathrm{a}}$ peak current ratio of the thioether complexes under study here.

When increasing quantities of 1 were added to a solution of bis(thioether) complex 3 the disappearance of the original waves of $\mathbf{3}$ and the appearance of a new, partially reversible couple at considerably lower oxidation potential of $+0.83 \mathrm{~V}$ was observed (Fig. 7). After addition of about half an equivalent of $\mathbf{1}$ this new couple constituted the prominent feature in the anodic regime. The product formed under these conditions was readily identified as the known mono(thioether) complex ( $p$-cymene) $\mathrm{RuCl}_{2}$ $\left(\mathrm{SMe}_{2}\right)(2 \mathrm{~d})$ by comparison with authentic material which

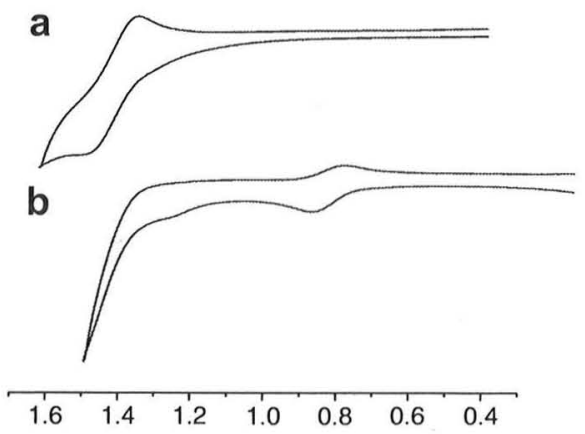

Fig. 7. Cyclic voltammograms of complex 3 in $\mathrm{CH}_{2} \mathrm{Cl}_{2} / \mathrm{NBu}_{4} \mathrm{PF}_{6}(0.1 \mathrm{M})$ at RT and $v=0.2 \mathrm{~V} / \mathrm{s}$ before (a) and after (b) addition of half an equivalent of $\mathbf{1}$. was independently synthesized [19]. We also verified clean formation of $\mathbf{2} \mathbf{d}$ when $\mathbf{1}$ and $\mathbf{3}$ were combined in an NMR tube and charged with $\mathrm{CD}_{2} \mathrm{Cl}_{2}$. This reaction provides another instance of the ready exchange of one $\mathrm{SMe}_{2}$ ligand from bis(thioether) complex 3 .

\section{Experimental}

NMR spectra were recorded on a Bruker AC 250 instrument at $303 \mathrm{~K}$. The spectra were referenced to the residual protonated solvent $\left({ }^{1} \mathrm{H}\right)$ or the solvent signal itself $\left({ }^{13} \mathrm{C}\right)$. For complexes $2 \mathbf{a}-\mathbf{d}$ and 3 the assignment of ${ }^{13} \mathrm{C}$ NMR spectra was aided by a DEPT-135 measurement. UV-Vis experiments were performed on an Omega 10 spectrometer by Bruins Instruments in HELMA quartz cuvettes whith $1 \mathrm{~cm}$ optical path lengths. Elemental analysis $(\mathrm{C}, \mathrm{H}, \mathrm{N})$ was performed at in-house facilities. Voltammograms were recorded on an EG\&G 273 or a BAS CV50 potentiostat in a home-built vacuum tight one-compartment cell using $\mathrm{Pt}$ or glassy carbon disk electrodes from BAS. \{ $p$-cymene) $\left.\mathrm{RuCl}_{2}\right\}_{2}$ (1) was prepared according to reference [41]. The new thioethers $\mathrm{PhC}_{2} \mathrm{H}_{4} \mathrm{SMe}$ and $\mathrm{PhC}_{3} \mathrm{H}_{6} \mathrm{~S}{ }^{i} \mathrm{Pr}$ were prepared from phenylethanthiol and methyl iodide or from ${ }^{i}$ propylthiol and 3-phenylpropylbromide following an established literature method [42] and were obtained in $74 \%$ and $76 \%$ yield following vacuum distillation. Spectroscopic data: (2-phenylpropyl)isopropyl sulfide: ${ }^{1} \mathrm{H}$ NMR $\left(\mathrm{CDCl}_{3}\right): \delta(\mathrm{ppm})=0.86\left(6 \mathrm{H}, \mathrm{d},{ }^{3} J_{\mathrm{HH}}=6.69 \mathrm{~Hz}, \mathrm{CH}_{3-}\right.$ $\left.\left({ }^{i} \mathrm{Pr}\right)\right), 1.92\left(2 \mathrm{H}, \mathrm{q},{ }^{3} \mathrm{~J}_{\mathrm{HH}}=7.35 \mathrm{~Hz}, \mathrm{CH}_{2} \mathrm{CH}_{2} \mathrm{CH}_{2}\right), 2.92$ $\left(1 \mathrm{H}\right.$, hept, $\left.{ }^{3} J_{\mathrm{HH}}=6.80 \mathrm{~Hz}, \mathrm{CH}\left({ }^{i} \mathrm{Pr}\right)\right), 2.55\left(2 \mathrm{H}, \mathrm{t},{ }^{3} J_{\mathrm{HH}}=\right.$ $\left.7.31 \mathrm{~Hz}, \mathrm{CH} \mathrm{H}_{2} \mathrm{Ph}\right), 2.73\left(2 \mathrm{H}, \mathrm{t},{ }^{3} J_{\mathrm{HH}}=7.58 \mathrm{CH}_{2} \mathrm{~S}\right), 7.24$ $(5 \mathrm{H}, \mathrm{m}, \mathrm{CH}(\mathrm{Ph})) ;{ }^{13} \mathrm{C} \mathrm{NMR}\left(\mathrm{CDCl}_{3}\right): \delta(\mathrm{ppm})=23.48$ $\left(\mathrm{CH}_{3}\left({ }^{i} \mathrm{Pr}\right)\right), 29.95\left(\mathrm{~s}, \mathrm{CH}_{2}\right), 32.42\left(\mathrm{~s}, \mathrm{CH}_{2} \mathrm{Ph}\right), 34.81$ (s, $\left.\mathrm{CH}\left({ }^{i} \mathrm{Pr}\right)\right), 35.01\left(\mathrm{~s}, \mathrm{CH}_{2} \mathrm{~S}\right), 125.90$ (s, $\left.p-\mathrm{CH}\right), 128.38$ (s, $m$ $\mathrm{CH}), 128.52$ (s, o-CH), $141.55\left(\mathrm{~s}, \mathrm{C}_{\text {quart }}\right)$; methyl(2-phenylethyl)sulfide: ${ }^{1} \mathrm{H}$ NMR $\left(\mathrm{CDCl}_{3}\right): \delta(\mathrm{ppm})=2.13(3 \mathrm{H}, \mathrm{s}$, $\left.\mathrm{CH}_{3} \mathrm{~S}\right), 2.76\left(2 \mathrm{H}, \mathrm{t},{ }^{3} \mathrm{~J}_{\mathrm{HH}}=8.0 \mathrm{~Hz}, \mathrm{CH}_{2} \mathrm{Ph}\right), 2.89(2 \mathrm{H}, \mathrm{t}$, $\left.{ }^{3} \mathrm{~J}_{\mathrm{HH}}=8.0 \mathrm{~Hz}, \mathrm{CH} \mathrm{S}_{2} \mathrm{~S}\right), 7.26(5 \mathrm{H}, \mathrm{m}, \mathrm{CH}(\mathrm{Ph})) ;{ }^{13} \mathrm{C} \mathrm{NMR}$ $\left(\mathrm{CDCl}_{3}\right): \delta(\mathrm{ppm})=15.63\left(\mathrm{~s}, \mathrm{CH}_{3} \mathrm{~S}\right), 35.75\left(\mathrm{~s}, \mathrm{CH}_{2} \mathrm{Ph}\right)$, $35.85\left(\mathrm{~s}, \mathrm{CH}_{2} \mathrm{~S}\right), 127.2(\mathrm{~s}, p-\mathrm{CH}), 128.15$ (s, m-CH), $128.57\left(\mathrm{~s}, o-C \mathrm{H}_{\mathrm{Ph}}\right), 140.13\left(\mathrm{~s}, \mathrm{C}_{\mathrm{quart}}\right)$.

\subsection{Synthesis of (p-cymene) $\mathrm{RuCl}_{2}\left(\mathrm{PhC}_{2} \mathrm{H}_{4} \mathrm{SMe}\right)$ (2a)}

A Schlenk tube was charged with $0.300 \mathrm{~g}(0.49 \mathrm{mmol})$ of $\left\{(p \text {-cymene }) \mathrm{RuCl}_{2}\right\}_{2}$ and a $223 \mu$ of $\mathrm{PhC}_{2} \mathrm{H}_{4} \mathrm{SMe}$ and the mixture stirred at room temperature overnight in $4 \mathrm{ml}$ of $\mathrm{CH}_{2} \mathrm{Cl}_{2}$. The solvent was evaporated and the crude product was washed with $2 \times 5 \mathrm{ml}$ of $\mathrm{Et}_{2} \mathrm{O}$. The orange powder obtained after drying in vacuo was dissolved in $3 \mathrm{ml}$ $\mathrm{CH}_{2} \mathrm{Cl}_{2}$, cautiously layered with the same quantity of $\mathrm{Et}_{2} \mathrm{O}$ and left to cool in a refrigerator. Compound 2a crystallized as long orange needles. Yield $65.4 \%(0.147 \mathrm{~g}$, $0.32 \mathrm{mmol}) .{ }^{1} \mathrm{H} \mathrm{NMR}\left(\mathrm{CDCl}_{3}\right): \delta(\mathrm{ppm})=1.26(6 \mathrm{H}, \mathrm{d}$, $\left.{ }^{3} J_{\mathrm{HH}}=6.86 \mathrm{~Hz}, \mathrm{CH}_{3}\left({ }^{i} \mathrm{Pr}\right)\right), 2.18,2.24$ (each s, $3 \mathrm{H}$, $\left.\mathrm{CH}_{3}(\mathrm{cym}), \mathrm{CH}_{3} \mathrm{~S}\right), 2.90\left(2 \mathrm{H}, \mathrm{m} \mathrm{CH} \mathrm{CH}_{2} \mathrm{Ph}\right), 2.92(2 \mathrm{H}, \mathrm{m}$, $\left.\mathrm{CH}_{2} \mathrm{~S}\right), 3.03\left(1 \mathrm{H}\right.$, hept, $\left.{ }^{3} J_{\mathrm{HH}}=6.86 \mathrm{~Hz}, \mathrm{CH}\left({ }^{i} \mathrm{Pr}\right)\right), 5.18$, 
$5.77\left(\right.$ each $\left.2 \mathrm{H}, \mathrm{d},{ }^{3} J_{\mathrm{HH}}=6.04 \mathrm{~Hz}, \mathrm{CH}(\mathrm{cym})\right), 7.26(5 \mathrm{H}, \mathrm{m}$, $\mathrm{CH}(\mathrm{Ph})) ;{ }^{13} \mathrm{C} \quad \mathrm{NMR} \quad\left(\mathrm{CDCl}_{3}\right): \quad \delta(\mathrm{ppm})=18.29, \quad 19.70$ $\left(\mathrm{CH}_{3}(\mathrm{cym}), \mathrm{CH}_{3} \mathrm{~S}\right), 22.20\left(\mathrm{CH}_{3}\left({ }^{i} \mathrm{Pr}\right)\right), 30.62\left(\mathrm{CH}\left({ }^{i} \mathrm{Pr}\right)\right)$, $33.97\left(\mathrm{CH}_{2} \mathrm{Ph}\right), 41.09\left(\mathrm{CH}_{2} \mathrm{~S}\right), 82.89(\mathrm{CH}(\mathrm{cym})), 83.93(\mathrm{~s}$, $\mathrm{CH}\left(\right.$ cym)), 99.30 (s, $\mathrm{C}_{\text {quart }}($ cym) $), 104.58$ (s, $\left.\mathrm{C}_{\text {quart }}(\mathrm{cym})\right)$, $126.78(\mathrm{~s}, p-\mathrm{CH}), 128.67(\mathrm{~s}, m-\mathrm{CH}), 128.72(\mathrm{~s}, o-\mathrm{CH})$, 139.15 (s, $\mathrm{C}_{\text {quart }}$ ). Anal. Calc. for $\mathrm{C}_{19} \mathrm{H}_{26} \mathrm{Cl}_{2} \mathrm{RuS}$ : C, 49.78; H, 5.72. Found: C, 49.73; H, 5.79.

\section{2. (p-Cymene) $\mathrm{RuCl}_{2}\left(\mathrm{PhC}_{3} \mathrm{H}_{6} \mathrm{~S}^{i} \mathrm{Pr}\right)(2 \boldsymbol{b})$}

$\mathrm{Ph}\left(\mathrm{CH}_{2}\right)_{3} \mathrm{~S}^{i} \operatorname{Pr}(193 \mu \mathrm{l}, 0.98 \mathrm{mmol})$ was added to $0.200 \mathrm{~g}$ $(0.326 \mathrm{mmol})$ of $\left\{(p \text {-cymene }) \mathrm{RuCl}_{2}\right\}_{2}$ dissolved in $5 \mathrm{ml}$ of $\mathrm{CH}_{2} \mathrm{Cl}_{2}$. The reaction mixture was stirred for $14 \mathrm{~h}$ at room temperature, then layered with $4 \mathrm{ml}$ of $\mathrm{EtOH}$ and left 5 days at room temperature. A small amount of a microcrystalline solid of 1 was formed and removed by canula filtration. The filtered solution was dried in vacuo. The dry residue was washed with $3 \times 4 \mathrm{ml}$ of $\mathrm{Et}_{2} \mathrm{O}$ and the $\mathrm{Et}_{2} \mathrm{O}$ removed after washing by canula filtration. The residue was then recrystallized two times from $\mathrm{CH}_{2} \mathrm{Cl}_{2} / \mathrm{Et}_{2} \mathrm{O}$ to give $2 \mathbf{b}$ as orange microcrystals. Yield: $0.296 \mathrm{~g}(0.59 \mathrm{mmol}$, $90.5 \%) .{ }^{1} \mathrm{H} \quad \mathrm{NMR}\left(\mathrm{CDCl}_{3}\right): \delta(\mathrm{ppm})=1.27 \quad(12 \mathrm{H}, \quad \mathrm{m}$, $\left.\mathrm{CH}_{3}\left({ }^{i} \mathrm{Pr}\right)\right), 1.88\left(2 \mathrm{H}, \mathrm{q},{ }^{3} J_{\mathrm{HH}}=7.57 \mathrm{~Hz}, \mathrm{CH}_{2} \mathrm{CH}_{2} \mathrm{CH}_{2}\right)$, $2.18\left(3 \mathrm{H}, \mathrm{s}, \mathrm{CH}_{3}(\mathrm{cym})\right), 2.64\left(4 \mathrm{H}, \mathrm{m}, \mathrm{CH}_{2}\right), 2.93(2 \mathrm{H}, \mathrm{m}$, $\left.\mathrm{CH}\left({ }^{i} \mathrm{Pr}\right)\right), \quad 5.21, \quad 5.38$ (each $2 \mathrm{H}, \quad \mathrm{d},{ }^{3} J_{\mathrm{HH}}=5.85 \mathrm{~Hz}$, $\mathrm{CH}(\mathrm{cym})), 7.21$ (5H, m, $\mathrm{CH}(\mathrm{Ph})) ;{ }^{13} \mathrm{C} \mathrm{NMR}\left(\mathrm{CDCl}_{3}\right)$ : $\delta(\mathrm{ppm})=18.90 \quad\left(\mathrm{CH}_{3}(\mathrm{cym})\right), \quad 22.14 \quad\left(\mathrm{CH}_{3}\left({ }^{i} \mathrm{Pr}\right)\right), \quad 30.36$ $\left(\mathrm{CH}_{2}\right), 30.61\left(\mathrm{CH}_{2} \mathrm{Ph}\right), 31.20\left(\mathrm{CH}\left({ }^{i} \mathrm{Pr}\right)\right), 34.89\left(\mathrm{CH}\left({ }^{i} \mathrm{Pr}\right)\right)$, $37.46\left(\mathrm{CH}_{2} \mathrm{~S}\right), 80.53,81.29(\mathrm{CH}(\mathrm{cym})), 96.74,101.23$ $\left(\mathrm{C}_{\text {quart }}(\mathrm{cym})\right), 125.90(p-\mathrm{CH}(\mathrm{Ph})), 128.38(\mathrm{~s}, m-\mathrm{CH}(\mathrm{Ph}))$, $128.50(\mathrm{~s}, o-\mathrm{CH}(\mathrm{Ph})), 141.55\left(\mathrm{~s}, \mathrm{C}_{\text {quart }}(\mathrm{Ph})\right)$. Anal. Calc. for $\mathrm{C}_{22} \mathrm{H}_{32} \mathrm{Cl}_{2} \mathrm{RuS}$ : C, 52.79; $\mathrm{H}, 6.44$. Found: C, 53.01; $\mathrm{H}, 6.55$.

\section{3. [(p-Cymene) $\mathrm{RuCl}_{2}\left(\mathrm{SMeC}_{3} \mathrm{H}_{5}\right) \mathrm{RuCl}_{2}(2 \mathrm{c})$}

$\left[\left\{(p \text {-Cymene }) \mathrm{RuCl}_{2}\right\}_{2}\right](0.120 \mathrm{~g}, 0.196 \mathrm{mmol})$ was dissolved in $6 \mathrm{ml}$ of $\mathrm{CH}_{2} \mathrm{Cl}_{2}$ and $52 \mu \mathrm{l}(0.591 \mathrm{mmol})$ of $\mathrm{SMeC}_{3} \mathrm{H}_{5}$ was added dropwise. The reaction mixture was stirred for $12 \mathrm{~h}$ at room temperature. The solvent was evaporated from the dark orange solution. The dry residue was washed with $3 \times 4 \mathrm{ml}$ of $\mathrm{Et}_{2} \mathrm{O}$ and the $\mathrm{Et}_{2} \mathrm{O}$ removed in vacuo. The resulting orange powder was dissolved in $3 \mathrm{ml}$ of $\mathrm{CH}_{2} \mathrm{Cl}_{2}$ and layered with $3 \mathrm{ml}$ of ether. After 3 days orange crystals were obtained. Yield $74.4 \% \quad(0.115 \mathrm{~g}$, $0.294 \mathrm{mmol}) .{ }^{1} \mathrm{H}$ NMR $\left(\mathrm{CDCl}_{3}\right): \delta(\mathrm{ppm})=1.24(6 \mathrm{H}, \mathrm{d}$, $\left.{ }^{3} J_{\mathrm{HH}}=6.95 \mathrm{~Hz}, \quad \mathrm{CH}_{3}\left({ }^{i} \mathrm{Pr}\right)\right), 2.15,217$ (each $3 \mathrm{H}, \mathrm{s}$, $\left.\mathrm{CH}_{3}(\mathrm{cym}), \quad \mathrm{CH}_{3} \mathrm{~S}\right), 2.92\left(1 \mathrm{H}\right.$, hept, ${ }^{3} J_{\mathrm{HH}}=6.95 \mathrm{~Hz}$, $\left.\mathrm{CH}\left({ }^{i} \mathrm{Pr}\right)\right), 3.36\left(2 \mathrm{H}, \mathrm{d},{ }^{3} J_{\mathrm{HH}}=7.3 \mathrm{~Hz}, \mathrm{CH}_{2} \mathrm{~S}\right), 5.17(2 \mathrm{H}, \mathrm{d}$ (br), $\left.{ }^{3} J_{\mathrm{HH}}=16 \mathrm{~Hz}, \mathrm{CH}=\mathrm{CH} H\right), 5.19(\mathrm{~d}, \mathrm{br}, \mathrm{CH}=\mathrm{C} H \mathrm{H}$, $\left.{ }^{3} J_{\mathrm{HH}}=10.8 \mathrm{~Hz}\right), 5.25,5.41\left(\right.$ each $2 \mathrm{H}, \mathrm{d},{ }^{3} J_{\mathrm{HH}}=5.66 \mathrm{~Hz}$, $\mathrm{CH}($ cym $)), 5.71\left(1 \mathrm{H}, \mathrm{ddt}, \mathrm{CH}=\mathrm{CHH},{ }^{3} J_{\mathrm{HH}}=16.0,10.8\right.$, $7.3 \mathrm{~Hz}) ;{ }^{13} \mathrm{C} \quad \mathrm{NMR} \quad\left(\mathrm{CDCl}_{3}\right): \quad \delta(\mathrm{ppm})=18.12, \quad 18.90$ $\left(\mathrm{CH}_{3} \mathrm{~S}, \mathrm{CH}_{3}(\mathrm{cym})\right), 22.14\left(\mathrm{CH}_{3}\left({ }^{i} \mathrm{Pr}\right)\right), 30.42\left(\mathrm{CH}\left({ }^{i} \mathrm{Pr}\right)\right)$, $40.69\left(\mathrm{CH}_{2} \mathrm{~S}\right), 82.87(\mathrm{CH}(\mathrm{cym})), 83.46(\mathrm{CH}(\mathrm{cym})), 98.76$ $\left(\mathrm{C}_{\text {quart }}(\mathrm{cym})\right), 104.42\left(\mathrm{C}_{\text {quart }}(\mathrm{cym})\right), 120.91 \quad(\mathrm{~s},=\mathrm{CH})$,
$130.87\left(\mathrm{~s},=\mathrm{CH}_{2}\right)$. Anal. Calc. for $\mathrm{C}_{14} \mathrm{H}_{22} \mathrm{Cl}_{2} \mathrm{RuS}$ : C, 46.41; H, 6.12. Found: C, 46.76; H, 6.14.

\section{4. $\left[(p \text {-Cymene }) \mathrm{RuCl}\left(\mathrm{SMe}_{2}\right)_{2}\right]^{+} \mathrm{SbF}_{6}^{-}$(3) and \\ $\left[\{(\text { p-cymene }) R u\}_{2}(\mu-C l)_{3}\right]^{+} S b F_{6}^{-}(4)$}

Following the procedure of Dixneuf [19], $0.200 \mathrm{~g}(0.326$ $\mathrm{mmol})$ of $\left\{(p \text {-cymene }) \mathrm{RuCl}_{2}\right\}_{2}, 0.176 \mathrm{~g}(0.68 \mathrm{mmol})$ of $\mathrm{NaSbF}_{6}$ and $190 \mu \mathrm{l}(2.61 \mathrm{mmol})$ of dimethyl sulfide were stirred with $8 \mathrm{ml}$ of $\mathrm{MeOH}$ for two days at room temperature. The resulting yellow mixture was evaporated to dryness and the residue was dissolved in $4 \mathrm{ml}$ of $\mathrm{CH}_{2} \mathrm{Cl}_{2}$. The solution was then filtered and the orange filtrate layered with $15 \mathrm{ml}$ of $\mathrm{Et}_{2} \mathrm{O}$. Orange crystals of 3 along with a small quantity of $\mathbf{4}$ formed upon slow diffusion of ether and were isolated by decantation of the solvent, dried in vacuo and then manually separated (3: orange diamonds, 4 orange needles). Yields were $230 \mathrm{mg}(55.9 \%)$ of 3 and $21 \mathrm{mg}(7.9 \%)$ of 4 . Compound 3: ${ }^{1} \mathrm{H}$ NMR $\left(\mathrm{CDCl}_{3}\right)$ : $\delta(\mathrm{ppm})=1.27\left(6 \mathrm{H}, \mathrm{d},{ }^{3} J_{\mathrm{HH}}=7.00 \mathrm{~Hz}, \mathrm{CH}_{3}\left({ }^{i} \mathrm{Pr}\right)\right), 2.21$ $\left(3 \mathrm{H}, \mathrm{s}, \mathrm{CH}_{3}(\mathrm{cym})\right), 2.27\left(6 \mathrm{H}, \mathrm{s}, \mathrm{CH}_{3} \mathrm{~S}\right), 2.96$ (2H, hept, $\left.{ }^{3} J_{\mathrm{HH}}=7.00 \mathrm{~Hz}, \mathrm{CH}\left({ }^{i} \mathrm{Pr}\right)\right), 5.20,5.40\left(\right.$ each $2 \mathrm{H}, \mathrm{d},{ }^{3} J_{\mathrm{HH}}=$ $6.01 \mathrm{~Hz}, \mathrm{CH}(\mathrm{cym})) ;{ }^{13} \mathrm{C} \mathrm{NMR}\left(\mathrm{CDCl}_{3}\right): \delta(\mathrm{ppm})=18.03$, $18.90\left(\mathrm{CH}_{3} \mathrm{~S}, \mathrm{CH}_{3}(\mathrm{cym})\right), 21.90\left(\mathrm{CH}_{3}\left({ }^{i} \mathrm{Pr}\right)\right), 31.44$ (s, $\left.\mathrm{CH}\left({ }^{i} \mathrm{Pr}\right)\right), 78.81$ (s, CH), $88.57(\mathrm{~s}, \mathrm{CH}), 101.83$ (C quart $^{-}$ $(\mathrm{cym})), 111.62\left(\mathrm{C}_{\text {quart }}(\mathrm{cym})\right)$. Anal. Calc. for $\mathrm{C}_{14} \mathrm{H}_{16} \mathrm{Cl}-$ $\mathrm{F}_{6} \mathrm{RuS}_{2} \mathrm{Sb}$ : C, 26.66; H, 4.15. Found: C, 26.85; H, 4.15.

\subsection{Compound 4}

${ }^{1} \mathrm{H}$ NMR $\left(\mathrm{CDCl}_{3}\right): \delta(\mathrm{ppm})=1.30\left(6 \mathrm{H}, \quad \mathrm{d},{ }^{3} J_{\mathrm{HH}}=\right.$ $\left.6.9 \mathrm{~Hz}, \mathrm{CH}_{3}\left({ }^{i} \mathrm{Pr}\right)\right), 2.22\left(3 \mathrm{H}, \mathrm{s}, \mathrm{CH}_{3}(\mathrm{cym})\right), 2.78$ (1H, hept, $\left.{ }^{3} J_{\mathrm{HH}}=6.9 \mathrm{~Hz}, \quad \mathrm{CH}\left({ }^{i} \mathrm{Pr}\right)\right), \quad 5.46, \quad 5.64$ (each $2 \mathrm{H}, \mathrm{d}$, $\left.{ }^{3} J_{\mathrm{HH}}=6.20 \mathrm{~Hz}, \mathrm{CH}\right) .{ }^{13} \mathrm{C} \quad \mathrm{NMR} \quad\left(\mathrm{CDCl}_{3}\right): \delta(\mathrm{ppm})=$ $18.96\left(\mathrm{CH}_{3}(\mathrm{cym})\right), 22.17\left(\mathrm{CH}_{3}\left({ }^{i} \mathrm{Pr}\right)\right), 30.63\left(\mathrm{CH}\left({ }^{i} \mathrm{Pr}\right)\right)$, $80.55,81.32$ (CH(cym)), $96.77\left(\mathrm{C}_{\text {quart }}(\mathrm{cym})\right), \quad 101.24$ $\left(\mathrm{C}_{\text {quart }}(\mathrm{cym})\right)$. Anal. Calc for $\mathrm{C}_{20} \mathrm{H}_{28} \mathrm{Cl}_{3} \mathrm{~F}_{6} \mathrm{Ru}_{2} \mathrm{Sb}$ : C, 29.55; H, 3.47. Found: C, 30.02; H, 3.55.

\section{X-ray crystallography}

X-ray-quality crystals were obtained as described in Section 5. Crystals were removed from Schlenk tubes and immediately covered with a layer of viscous hydrocarbon oil (Paratone N, Exxon). A suitable crystal was selected, attached to a glass fiber, and, in the case of $2 \mathrm{c}$, instantly placed in a low-temperature $\mathrm{N}_{2}$-stream [43]. All data were collected at $293 \mathrm{~K}(\mathbf{2 a}, \mathbf{3}, \mathbf{4})$ or $173 \mathrm{~K}$ (2c) using either a Bruker-Nonius Kappa CCD $(2 \mathbf{a}, 3,4)$ or a rebuilt Syntex P2 1 Siemens P3 (2c) diffractometer. Crystal data are given in Table 3. Calculations were carried out with the SHELXTL PC 5.03 [44] and SHELXL-97 [45] program system installed on a local PC. The structures were solved by direct methods and refined on $F_{\mathrm{o}}^{2}$ by full-matrix least-squares refinement. An absorption correction was applied by using semiempirical $\psi$-scans $(2 \mathrm{c})$ or by a numerical absorption correction $(2 \mathbf{a}, 3,4)[46]$. In $2 \mathbf{c}$ the disorder in the allyl group of the 
thioether ligand was modeled with split positions (s.o.f. $=0.667 / 0.333$ for C14/C14a) and DFIX constraints for the $\mathrm{C} 13-\mathrm{C} 14$, and $\mathrm{C} 13-\mathrm{C} 14 \mathrm{a}$ distances. Anisotropic thermal parameters were included for all non-hydrogen atoms with the exception of the two disordered carbon atoms. $\mathrm{H}$ atoms were placed geometrically and refined using a riding model, including free rotation of methyl groups and variable isotropic displacement parameters. Final $R$ values are listed in Table 3. Important bond parameters are given in Tables 1 and 2.

\section{Acknowledgements}

Financial support of this work by Deutsche Forschungsgemeinschaft (Grant Wi1262/4-1) is gratefully acknowledged. RFW also wishes to thank Dr. Reiner Ruf for his help with the structure refinement of complex 3 .

\section{Appendix A. Supplementary material}

CCDC $611182,611183,611184$ and 611185 contain the supplementary crystallographic data for $2 a, 2 c, 3$ and 4 . These data can be obtained free of charge via htpp:// www.ccdc.cam.ac.uk/conts/retrieving.html, or from the Cambridge Crystallographic Data Centre, 12 Union Road, Cambridge CB2 1EZ, UK; fax: (+44) 1223-336-033; or e-mail: deposit@ccdc.cam.ac.uk. Supplementary data associated with this article can be found, in the online version, at doi:10.1016/j.jorganchem.2006.11.046.

\section{References}

[1] A. Fürstner, M. Picquet, C. Bruneau, P.H. Dixneuf, Chem. Commun. (1998) 1315.

[2] A. Fürstner, L. Ackermann, Chem. Commun. (1999) 95.

[3] A. Fürstner, M. Liebl, C.W. Lehmann, M. Picquet, R. Kunz, C. Bruneau, D. Touchard, P.H. Dixneuf, Chem. Eur. J. 6 (2000) 1847.

[4] R. Castarlenas, D. Sémeril, A.F. Noels, A. Demonceau, P.H. Dixneuf, J. Organomet. Chem. 663 (2002) 235.

[5] R. Castarlenas, P.H. Dixneuf, Angew. Chem. 115 (2003) 4662.

[6] M. Bassetti, F. Centola, D. Sémeril, C. Bruneau, P.K. Dixneuf, Organometallics 22 (2003) 4459.

[7] F. Simal, A. Demonceau, A.F. Noels, Angew. Chem., Int. Ed. Engl. 38 (1999) 538.

[8] F. Simal, S. Sebille, L. Hallet, A. Demonceau, A.F. Noels, Macormol. Symp. 161 (2000) 73.

[9] V. Cadierno, P. Crochet, S.E. García-Carrido, J. Gimeno, Dalton Trans. (2004) 3635.

[10] K.-J. Haack, S. Hashiguchi, A. Fujii, T. Ikariya, R. Noyori, Angew. Chem., Int. Ed. Engl. 36 (1996) 285.

[11] R. Noyori, S. Hashiguchi, Acc: Chem. Res. 31 (1997) 97.

[12] M. Yamakawa, I. Yamada, R. Noyori, Angew. Chem., Int. Ed. Engl. 40 (2001) 2818

[13] R. Noyori, Angew. Chem., Int. Ed. Engl. 41 (2002) 2008.
[14] C.J. Boxwell, P.J. Dyson, D.J. Ellis, T. Welton, J. Am. Chem. Soc. 124 (2002) 9334.

[15] J.F. Faller, B.J. Grimmond, Organometallics 20 (2001) 2454.

[16] D.L. Davies, J. Fawcett, S.A. Garratt, D.R. Russell, Organometallics 20 (2001) 3029.

[17] S. Ogo, T. Abura, Y. Watanabe, Organometallics 21 (2002) 2964.

[18] S. Ogo, K. Uehara, T. Abura, Y. Watanabe, S. Fukuzumi, Organometallics 23 (2004) 3047.

[19] M. Gaye, B. Demerseman, P.H. Dixneuf, J. Organomet. Chem. 411 (1991) 263.

[20] Y. Yamamoto, S. Sakamoto, Y. Ohki, A. Usuzawa, M. Fujita, T. Mochida, Dalton Trans. (2003) 3534.

[21] M.A. Bennett, L.Y. Goh, A.C. Willis, J. Am. Chem. Soc. 118 (1996) 4984.

[22] R.Y.C. Shin, M.A. Bennett, L.Y. Goh, W. Chen, D.C.R. Hockless, W.K. Leong, K. Mashima, A.C. Willis, Inorg. Chem. 42 (2003) 96.

[23] R.Y.C. Shin, S.Y. Ng, G.K. Tan, L.L. Koh, S.B. Khoo, L.Y. Goh, R.D. Webster, Organometallics 23 (2004) 547.

[24] G. Tresoldi, L. Baradello, S. Lanza, P. Cardiano, Eur. J. Inorg. Chem. (2005) 2423.

[25] P.D. Smith, A.H. Wright, J. Orgnanomet. Chem. 559 (1998) 141.

[26] M.A. Bennett, A.J. Edwards, J.R. Harper, T. Khimyak, A.C. Willis, J. Organomet. Chem. 629 (2001) 7.

[27] K. Umezawa-Vizzini, I.Y. Guzman-Jimenez, K.H. Whitmire, T.R. Lee, Organometallics 22 (2003) 3059.

[28] K. Umezawa-Vizzini, T.R. Lee, Organometallics 22 (2003) 3066.

[29] K. Umezawa-Vizzini, T.R. Lee, Organometallics 23 (2004) 1448.

[30] L. Carter, D.L. Davies, J. Fawcett, D.R. Russell, Polyhedron 12 (1993) 1123.

[31] R. Aronson, M.R. Elsegood, J.W. Steed, D.A. Tocher, Polyhedron 10 (1991) 1727.

[32] G.A. Heath, G. Hefter, D.R. Robertson, W.J. Sime, T.A. Stephenson, J. Organomet. Chem. 152 (1978) Cl.

[33] F. Greponi, D. Braga, P.J. Dyson, B.F.G. Johnson, F.M. Sanderson, M.J. Calhorda, L.F. Veiros, Organometallics 14 (1995) 121.

[34] D.S. Pandey, A.N. Sahay, O.S. Sisoida, N.K. Jha, P. Sharma, H.E. Klaus, A. Caberra, J. Organomet. Chem. 592 (1999) 278.

[35] J. Soleimannejad, C. White, Organometallics 24 (2005) 2538.

[36] D.A. Tocher, M.D. Walkinshaw, Acta Crystallogr., Sect. B 38 (1982) 3083.

[37] B. Therrien, L. Vieille-Petit, J. Jeanette-Gris, P. Stepnicka, G. SüssFink, J. Organomet. Chem. 689 (2004) 2456.

[38] J. Cubrilo, I. Hartenbach, T. Schleid, R.F. Winter, Z. Anorg. Allg. Chem. 632 (2006) 400.

[39] G. Bhalla, J. Oxgaard, W.A. Goddard III, R. Periana, Organometallics 24 (2005) 5499.

[40] P. Lahuerta, J. Latorre, J. Soto, Y. Mugnier, Polyhedron 8 (1989) 2803.

[41] M.A. Bennett, T.-N. Huang, T.W. Matheson, A.K. Smith, S. Ittel, W. Nickerson, in: J.F. Fackler (Ed.), Inorg. Synth. 21 (1974) 75.

[42] P. Cagniant, G. Jecko, D. Cagniant, Bull. Soc. Chim. Fr. (1960) 1798.

[43] H. Hope, Prog. Inorg. Chem. 41 (1995) 1.

[44] SHELXTL PC 5.03, 5.03, Siemens Analytical X-Ray Instruments Inc., Madison, WI, 1994.

[45] G.M. Sheldrick, SHElx-97, Program for ${ }^{-}$Crystal Structure Solution and Refinement, Institut für Anorganische Chemie der Universität, Tammanstraße 4, Göttingen, 1997.

[46] W. Herrendorf, H. Bärnighausen, Program HABITUS, Karlsruhe, Germany, 1993. 